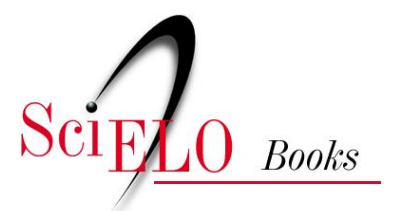

\title{
Travessia do cambaio
}

\author{
Euclides da Cunha
}

\section{SciELO Books / SciELO Livros / SciELO Libros}

CUNHA, E. Travessia do cambaio. In: Os sertões [online]. Rio de Janeiro: Centro Edelstein de Pesquisas Sociais, 2010. pp. 209-239. ISBN: 978-85-7982-007-6.

https://doi.org/10.7476/9788579820076.0005.

\section{() povour}

This work is free of known copyright restrictions. http://creativecommons.org/publicdomain/mark/1.0/

Este trabalho está livre de restrições de direito de autor e/ou de direitos conexos conhecidas.

http://creativecommons.org/publicdomain/mark/1.0/

Esta obra está libre de restricciones conocidas de derechos autorales. http://creativecommons.org/publicdomain/mark/1.0/ 


\section{TRAVESSIA DO CAMBAIO}

I. Monte Santo. Triunfos antecipados.

II. Incompreensão da campanha. Em marcha para Canudos.

III. O Cambaio. Baluartes sine calcii linimenti. Primeiro recontro. Episódio dramático.

IV. Nos Tabuleirinhos. Segundo combate. A Legio Fulminata de João Abade. Novo milagre de Antônio Conselheiro.

V. Retirada.

VI. Procissão dos jiraus. 


\section{Capítulo I}

\section{Monte Santo} Santo.

No dia 29 de dezembro entraram os expedicionários em Monte

O povoado de frei Apolônio de Todi ia, a partir daquela data, celebrizar-se como base das operações de todas as arremetidas contra Canudos. Era o que mais se avantajava por aqueles sertões em fora na direção do objetivo da campanha, permitindo, além disto, mais rápidas comunicações com o litoral, por intermédio da estação de Queimadas.

A tais requisitos aliavam-se outros.

Vimos-lhe em páginas anteriores a gênese tocante.

Não dissemos, porém, que, criando-o, o estoico Anchieta do Norte aquilatara bem as condições privilegiadas do local.

De fato, a vila - ereta no sopé da serrania de onde promana a única fonte perene da redondeza - contrasta, insulada, com a esterilidade ambiente. Decorre isto de sua situação topográfica. A sublevação de rochas primitivas que se alteiam aos lados, para o norte e para leste, levanta-se como anteparo aos ventos regulares, que até lá progridem, e torna-se condensador admirável dos escassos vapores que ainda os impregnam, graças ao resfriamento decorrente de uma ascensão repentina pelos flancos das serranias. Depõem-se, então, aqueles, em chuvas quase regulares, originando regime climatológico mais suportável, a dois passos dos sertões estéreis para onde rolam, mais secos, os ventos, depois da travessia.

De sorte que enquanto em roda se desenrolam plainos desolados, num raio de alguns quilômetros partindo de Monte Santo se estende região incomparavelmente mais vivaz. Recortam-na pequenos cursos d'água resistentes às secas. Pelas baixadas, para onde descaem os morros, notam-se rudimentos de florestas, transmudando-se as caatingas em cerradões virentes; e o Rio de Cariacá com seus tributários minúsculos, embora efêmero como os demais das cercanias, não se esgota de todo nas maiores secas: fraciona-se, retalhado em cacimbas reduzidas a imperceptíveis filetes deslizando entre pedras, mas permitindo ainda que resistam ao flagelo os habitantes convizinhos.

É natural que seja Monte Santo, desde muito, uma paragem remansada, predileta aos que se aventuram naquele sertão bravio. Não surgia pela primeira vez na história. Muito antes dos que agora o procuravam, outros expedicionários, por ventura mais destemerosos e, com certeza, mais interessantes, por ali haviam passado, norteados por outros desígnios. Mas quer para os bandeirantes do século XVII, quer para os soldados destes tempos, o lugar predestinado constituiu-se escala transitória e breve, mal relumbrando em acontecimentos de maior monta. Não deixa, contudo, de ser expressiva a sua função histórica, entre devassadores de sertão, distintos por opostos intuitos e desunidos por três séculos, porém tendo - como veremos - a afinidade dos mesmos rancores e das mesmas arrancadas violentas.

Ali estacionara o pai de Robério Dias, Belchior Moréia, na sua rota atrevida "do rio Real para as serras da Jacobina pelo rio Itapicuru acima, buscando os sertões de Maçacará". E em torno desta entrada, continuaram outras, orientadas pelos roteiros confusos, nos quais, todavia, o antigo nome da serra — Piquaraçá — se lê sempre, demarcando uma paragem benfazeja naqueles terrenos agros.

Por isto centralizou, de algum modo, a primeira agitação feita em torno das lendárias "Minas de Prata", desde as pesquisas inúteis do Muribeca, que até lá chegara e não passara avante, "com pouco efeito e pouca diligência”, até ao tenaz Pedro Barbosa Leal, acompanhando as trilhas de Moréia e estacionando por muitos dias na montanha, onde marcas indecifráveis denotavam a passagem de antecessores igualmente audazes.

Passaram-se, porém, os tempos. Ficou perdida no sertão a serrania misteriosa onde muitos imaginavam, talvez, a sede do eldorado apetecido, ate que Apolônio de Todi a transformasse em templo majestoso e rude, como vimos.

E hoje quem segue pelo caminho de Queimadas, trilhando um solo abrolhando cactos e pedras, ao divisá-la, das cercanias de Quirinquinquá, duas léguas aquém, - estaca: volve em cheio pare o levante a vista deslumbrada, e acredita que o ondular dos ares referventes e a fascinação da 
luz lhe alteiam defronte, entre o firmamento claro e as chapadas amplas, uma miragem estonteadora e grande.

A serra feita dessa massa de quartzito, tão própria às arquiteturas monumentais da Terra, alteia-se, ao longe, acrescida a altitude pelas várzeas deprimidas em torno. Lança, retilínea, a linha de cumeadas. A vertente oriental cai, a pique, lembrando uma muralha, sobre o vilarejo. Este ali se encosta, sobre o socalco breve, humílimo, assoberbado pela majestade da montanha.

Entretanto é por esta acima até ao vértice que se prolonga, saindo da praça, a mais bela de suas ruas - a via-sacra dos sertões, macadamizada de quartzito alvíssimo, por onde tem passado multidões sem conta em um século de romarias. A religiosidade ingênua dos matutos ali talhou, em milhares de degraus, coleante, em caracol pelas ladeiras sucessivas, aquela vereda branca de sílica, longa de mais de dois quilômetros, como se construísse uma escada pare os céus...

\section{Esta ilusão é empolgante ao longe.}

Veem-se as capelinhas alvas, que a pontilham a espaços, subindo a princípio em rampa fortíssima, derivando depois, tornejantes, à feição dos pendores; alteando-se sempre, erectas sobre despenhadeiros, perdendo-se nas alturas, cada vez menores, diluídas a pouco e pouco no azul puríssimo dos ares, até à última, no alto...

E quem segue pelo caminho de Queimadas, atravessando um esboço do deserto, onde agonize uma flora de gravetos - arbustos que nos esgalhos revoltos retratam contorções de espasmos, cardos agarrados a pedras ao modo de tentáculos constritores, bromélias desabotoando em floração sanguinolenta - avança rápido, ansiando pela paragem que o arrebata.

Chega; e não sofreia doloroso desapontamento.

A estrada vai até à praça, retangular, em declive, de chão estriado de enxurros. No centro o indefectível barracão da feira tem, ao lado, pequena igreja, e de outro o único ornamento da vila - um tamarineiro, secular talvez. Em torno casas baixas e velhas; e, sobressaído, um sobrado único que seria mais tarde o quartel-general das tropas.
Monte Santo, afinal, resume-se naquele largo. Ali desembocam pequenas ruas, descendo umas em ladeiras para larga sanga apaulada; abrindo outras para a várzea; outras embatendo, sem saídas, contra a serra.

Esta por sua vez, de perto, perde parte do encanto. Parece diminuir de altitude. Sem mais o perfil regular que assume a distância, tem, revestindolhe as encostas, uma flora de vivacidade inexplicável, arraigada na pedra, brotando pelas frinchas dos estratos e vivendo apenas das reações maravilhosas da luz. As capelinhas, tão brancas de longe, por sua vez aparecem exíguas e descuradas. E a estrada ciclópica de muros laterais, de alvenaria, a desabarem em certos trechos, cheia de degraus fendidos, tortuosa, lembra uma enorme escadaria em ruínas. O povoado triste e de todo decadente reflete o mesmo abandono, traindo os desalentos de uma raça que morre, desconhecida à Historia, entre paredes de taipa. Nada recorda o encanto clássico das aldeias. As casas baixas, unidas umas contra as outras, feitas à feição dos acidentes do solo, têm todas a mesma forma tetos deprimidos sobre quatro muros de barro — gizadas todas por esse estilo brutalmente chato a que tanto se afeiçoavam os primitivos colonizadores. Algumas devem ter cem anos. As mais novas, copiandolhes, linha a linha, os contornos desgraciosos, por sua vez nascem velhas.

Deste modo, Monte Santo surge desgracioso dentro de uma natureza que lhe cria em roda - como um parêntese naquele sertão aspérrimo situação aprazível e ridente.

A campanha incipiente ia agravar o seu aspecto. Menos que arraial obscuro, transformá-lo-ia em grandíssimo quartel acaçapado, envolto de casernas.

\section{Triunfos antecipados}

Ali acantonaram as 543 praças, 14 oficiais combatentes e 3 médicos - toda a primeira expedição regular contra Canudos. Era uma massa heterogênea de três cascos de batalhões, o $9^{\circ}$, o $26^{\circ}$ e o $33^{\circ}$, tendo, adidas, duzentas e tantas praças de polícia e pequena divisão de artilharia, dois canhões Krupp 7 1 1/2 e duas metralhadoras Nordenfelt.

Menos de uma brigada, pouco mais de um batalhão completo. 
Entretanto, afinados pelo otimismo oficial, as autoridades receberam os lutadores em triunfo, antes da batalha. Engalanou-se o vilarejo pobre, transfigurando-se, ataviado de bandeiras e ramagens, com o ornamento supletivo dos vivos fortes das fardas e irradiação das armas.

E fez-se um dia de festa. A missão mais concorrida, a mais animada feira, jamais tiveram tanto brilho. Tudo aquilo era uma novidade estupenda. Ao chegarem da rota fatigante, rompendo, surpreendidos, pelas ruas cheias de combatentes, os vaqueiros amarravam o campeão à sombra do tamarineiro, na praça, e iam quedar-se, longo tempo, contemplando as peças em que tanto ouviam falar e nunca haviam visto, capazes de esboroar montanhas e abalar com um só tiro, mais forte que o de mil roqueiras, o sertão inteiro. E aqueles titãs, enrijados pelos climas duros, estremeciam dentro das armaduras de couro considerando as armas portentosas da civilização.

Galgavam, muitos, logo, os lombilhos retovados e largavam, transidos de susto, da vila, demandando a caatinga. Alguns volviam a toda a brida para o norte, tocando para Canudos. Ninguém os percebia. Na alacridade dos festejos, não se distinguiam os emissários solertes de Antônio Conselheiro - espiando, observando, indagando, contando o numero de praças, examinando todo o trem de guerra e desaparecendo depois, rápidos, precipitando-se para a aldeia sagrada.

Outros ali ficavam, encapotados, contemplando tudo aquilo com ironia cruel, certos do prelúdio hilariante de um drama doloroso. O profeta não podia errar: a sua vitória era fatal. Dissera-o — os invasores não veriam sequer as torres das igrejas sacrossantas.

Acendiam-se recônditos altares. E o riso dos soldados, e o estrépito das botas, percutindo as calcadas, e o vibrar dos clarins, e os vivas entusiásticos das ruas coavam-se pelas paredes, penetravam as frestas das casas e iam perturbar, lá dentro, as preces abafadas dos fiéis genuflexos...

No banquete, preparado na melhor vivenda, ao mesmo tempo se ostentava o mais simples e emocionante gênero de oratória - a eloquência militar, esta eloquência singular do soldado, que é tanto mais expressiva quanto é mais rude - feita de frases sacudidas e breves, como as vozes de comando, e em que as palavras mágicas - Pátria, Glória e Liberdade ditas em todos os tons, são toda a matéria-prima dos períodos retumbantes.
Os rebeldes seriam destruídos a ferro e fogo... Como as rodas dos carros de Shiva, as rodas dos canhões Krupp, rodando pelas chapadas amplas, rodando pelas serranias altas, rodando pelos tabuleiros vastos, deixariam sulcos sanguinolentos. Era preciso um grande exemplo e uma lição. Os rudes impenitentes, os criminosos retardatários, que tinham a gravíssima culpa de um apego estúpido às mais antigas tradições, requeriam corretivo enérgico. Era preciso que saíssem afinal da barbaria em que escandalizavam o nosso tempo, e entrassem repentinamente pela civilização adentro, a pranchadas.

O exemplo seria dado. Era a convicção geral. Dizia-o a despreocupação e todo o arrebatamento feliz de uma população inteira; e a alegria ruidosa e vibrante dos oficiais e das praças; e toda aquela festa - ali - na véspera dos combates, a dois passos do sertão referto de emboscadas...

À tarde grupos ruidosos salpintavam a praça. Derivavam pelos becos. Espalhavam-se pelas cercanias. Atraídos pela novidade de uma perspectiva rara, outros ascendiam a montanha pela ladeira sinuosa orlada de capelinhas brancas.

Paravam nos passos, refazendo-se para a ascensão exaustiva. Examinavam, curiosos, os registros e estampas, que pendiam as paredes, e os altares toscos; e subiam.

No "alto da Santa Cruz", batidos pelas lufadas fortes do nordeste, consideravam em torno.

Ali estava — defronte - o sertão...

Uma breve opressão salteava os mais tímidos; mas desaparecia prestes. Volviam tranquilos para a vila, onde se acendiam as primeiras luzes, ao cair da noite...

Decididamente a campanha começara bem auspiciada.

Monte Santo antecipara-lhe as honras da vitória. 


\section{Capítulo II}

\section{Incompreensão da campanha}

Foi um mal.

Sob a sugestão de um aparato bélico, de parada, os habitantes preestabeleceram o triunfo; invadida pelo contágio desta crença espontânea, a tropa, por sua vez, compartiu-lhes as esperanças.

Firmara-se, de antemão, a derrota dos fanáticos.

Ora, nos sucessos guerreiros entra, como elemento paradoxal embora, a preocupação da derrota. Está nela o melhor estímulo dos que vencem. A história militar é toda feita de contrastes singulares. Além disto a guerra é uma coisa monstruosa e ilógica em tudo. Na sua maneira atual é uma organização técnica superior. Mas inquinam-na todos os estigmas do banditismo original. Sobranceiras ao rigorismo da estratégia, aos preceitos da tática, à segurança dos aparelhos sinistros, a toda a altitude de uma arte sombria, que põe dentro da frieza de uma fórmula matemática o arrebentamento de um shrapnel e subordina a parábolas invioláveis o curso violento das balas, permanecem - intactas - todas as brutalidades do homem primitivo. E estas são, ainda, a vis a tergo dos combates.

A certeza do perigo estimula-as. A certeza da vitoria deprime-as.

Ora, a expedição ia, na opinião de toda a gente, positivamente vencer. A consciência do perigo determinaria mobilização rápida e um investir surpreendedor com o adversário. A certeza do sucesso imobilizou-a quinze dias em Monte Santo.

Analisemos o caso. O comandante expedicionário deixara em Queimadas grande parte de munições, para não protelar por mais tempo a marcha e impedir que os inimigos ainda mais se robustecessem. Assim, teve o intento de uma arremetida fulminante. Revoltado com as dificuldades que encontrara, entre as quais se notava quase completa carência de elementos de transporte, dispusera-se a ir celeremente ao couto dos rebeldes, embora levando apenas a munição que as praças pudessem carregar nas patronas. Isto, porém, não se realizou. De sorte que a partida rápida de uma localidade condena a demora inconsequente na outra. Esta somente se justificaria se, ponderando melhor a seriedade das coisas, ele a aproveitasse para agremiar melhores elementos, fazendo vir de Queimadas o resto dos trens de guerra. Os inconvenientes de uma longa pausa, justificá-los-iam as vantagens adquiridas. Ganharia em força o que perdesse em celeridade. Às aventuras de um plano temerário, resumindo-se numa investida e num assalto, substituiria operação mais lenta e mais segura. Não fez isto. Fez o inverso: depois de longa inatividade em Monte Santo, a expedição partiu ainda menos aparelhada do que quando ali chegara quinze dias antes, abandonando, ainda uma vez, parte dos restos de um trem de guerra já muitíssimo reduzido. Entretanto, contravindo ao modo de ver dos propagandistas de uma vitória fácil, chegavam constantes informações sobre o número e recursos dos fanáticos. E no disparatado das opiniões entre as que elevavam aquele, no máximo, a quinhentos, e as que o firmavam, decuplicando-o, no mínimo, em cinco mil, cumpria inferir-se uma média razoável. Além disto, de envolta num sussurrar de cautelosas denúncias e mal boquejados avisos, esboçava-se a hipótese de uma traição. Apontavam-se influentes mandões locais, cujas velhas relações com o Conselheiro sugeriam, veemente, a presunção de que o estivessem auxiliando à socapa, fornecendo-lhe recursos e instruindo-o dos menores movimentos da investida. Ainda mais, sabia-se que a tropa, quando mesmo o maior sigilo rodeasse as deliberações, seria, no avançar, precedida e ladeada pelos espias espertos do inimigo, muitos dos quais, verificou-se depois, dentro da própria vila acotovelavam os expedicionários. Uma surpresa, depois de tantos dias perdidos e em tais circunstâncias, era inadmissível. Em Canudos saberiam da estrada escolhida pare a linha de operações com antecedência bastante pare se fortificarem os seus trechos mais difíceis, de sorte que, reeditando o caso de Uauá, o alcance do arraial preestabelecia a preliminar de um combate em caminho. Assim a partida da base de operações, do modo por que se fez, foi um erro de ofício. A expedição endireitava pare o objetivo da luta como se voltasse de uma campanha. Abandonando novamente parte das munições, seguia como se, pobre de recursos em Queimadas, paupérrima de recursos em Monte Santo, ela fosse abastecer-se - em Canudos... Desarmava-se à medida que se aproximava do inimigo. Afrontava-se com o desconhecido, ao acaso, tendo o amparo único da fragilidade de nossa bravura impulsiva.

A derrota era inevitável. 
Porque a tais deslizes se aditaram outros, denunciando a mais completa ignorância da guerra.

Revela-a a ordem do dia organizadora das forças atacantes.

Escassa como uma ordem qualquer distribuindo contingentes, não há rastrear-se nela a mais fugaz indicação sobre o desdobramento, formaturas ou manobras das unidades combatentes, consoante os vários casos fáceis de prever. Não há uma palavra sobre inevitáveis assaltos repentinos. Nada, afinal, visando uma distribuição de unidades, de acordo com os caracteres especiais do adversário e do terreno. Adstrito a uns rudimentos de tática prussiana, transplantados as nossas ordenanças, o chefe expedicionário, como se levasse o pequeno corpo de exército pare algum campo esmoitado da Bélgica, dividiu-o em três colunas, parecendo dispô-lo, de antemão, para recontros em que lhe fosse dado entrar repartindo em atiradores, reforço e apoio. Nada mais, além desse subordinar-se a uns tantos moldes rígidos de velhos ditames clássicos de guerra.

\section{Ora, estes eram inadaptáveis no momento.}

Segundo o exato conceito de Von der Goltz, qualquer organização militar deve refletir alguma coisa do temperamento nacional. Entre a incoercível tática prussiana, em que é tudo a precisão mecânica da bala, e a nervosa tática latina, em que é tudo arrojo cavalheiresco da espada, tínhamos a esgrima perigosa com os guerrilheiros esquivos cuja força estava na própria fraqueza, na fuga sistemática, num vaivém doidejante de arrancadas e recuos, dispersos, escapantes do seio da natureza protetora. Eram por igual inúteis as cargas e as descargas. Contra tais antagonistas e num tal terreno não havia supor-se a probabilidade de se estender a mais apagada linha de combate. Não havia até a possibilidade de um combate no rigorismo técnico do termo. A luta, digamos com mais acerto, uma monteria a homens, uma batida brutal em torno à ceva monstruosa de Canudos, ia reduzir-se a ataques ferozes, a esperas ardilosas, a súbitas refregas, instantâneos recontros em que fora absurdo admitir-se que se pudessem desenvolver as fases principais daquele, entre os dois extremos dos fogos violentos, que o iniciam, o epílogo delirante das cargas de baioneta. Função do homem e do solo, aquela guerra devia impulsionar-se a golpes de mão de estrategista revolucionário e inovador. Nela iam surgir, tumultuariamente, fundidas, penetrando-se, simultâneas, todas as situações, naturalmente distintas, em que se pode encontrar qualquer força em operações - a de repouso, a de marcha e a de combate. O exército marchando pronto a encontrar o inimigo em todas as voltas dos caminhos, ou a vê-lo romper dentre as próprias fileiras surpreendidas, devia repousar nos alinhamentos da batalha.

Nada se deliberou quanto a condições tão imperiosas. O comandante limitou-se a formar três colunas e a ir para a frente, pondo diante da astúcia sutil dos jagunços a potência ronceira de três falanges compactas homens inermes carregando armas magníficas. Ora, um chefe militar deve ter algo de psicológico. Por mais mecanizado que fique o soldado pela disciplina, tendendo para esse sinistro ideal de homúnculo, feito um feixe de ossos amarrados por um feixe de músculos, energias inconscientes sobre alavancas rígidas, sem nervos, sem temperamento, sem arbítrio, agindo como um autômato pela vibração dos clarins, transfiguram-no as emoções da guerra. E a marcha nos sertões desperta-as a todo o instante. Trilhando veredas desconhecidas, envolto por uma natureza selvagem e pobre, o nosso soldado, que é corajoso na frente do inimigo, acovarda-se, invadido de temores, todas as vezes que este, sem aparecer, se revela, impalpável dentro das tocaias. Assim, se um tiroteio das guardas de frente se constitui, na campanha, aviso salutar ao resto dos lutadores, naquelas circunstâncias anormais era um perigo. Quase sempre as seções se baralhavam, sacudidas pelo mesmo espanto, numa desordem súbita, tendendo a um refluxo instintivo para a retaguarda.

Era natural que fossem previstas estas conjunturas inevitáveis. Para atenuá-las, as diversas unidades deviam seguir com o máximo afastamento, embora agissem, no primeiro momento, completamente isoladas. Este dispositivo, além de lhes altear o ânimo, pela certeza de um pronto auxílio por parte das que fora da ação imediata do inimigo podiam acometê-lo levando a força moral do ataque, evitava o alastramento do pânico e facultava um desdobramento desafogado. Embora a direção dos vários movimentos escapasse da autoridade de um comando único, substituída pela iniciativa mais eficaz dos comandantes de pequenas unidades, agindo autônomas de acordo com as circunstâncias do momento, impunha-se largo fracionamento das colunas. Era parodiar a norma guerreira do adversário, seguindo-a paralelamente, em traçados mais firmes e opondo-lhe a mesma dispersão, única capaz de amortecer as causas de insucesso de anular o 
efeito de repentinas emboscadas, de criar melhores recursos de reação, e de acarretar, ao cabo, a vitória, do único modo por que esta poderia ser alcançada, feito uma soma de sucessivos ataques parciais.

Em síntese, as forças, dispersas em marcha, a partir da base das operações, deviam ir, a pouco e pouco, apertando os fanáticos, concentrarse em Canudos.

Fez-se sempre o contrário. Partiam unidas, em colunas dentro da estrutura maciça das brigadas. Avançavam emboladas pelos caminhos em fora. Iam dispersar-se, repentinamente - em Canudos...

\section{Em marcha para Canudos} 1897.

Foi nestas condições desfavoráveis que partiram a 12 de janeiro de

\section{Tomaram pela estrada do Cambaio.}

É a mais curta e a mais acidentada. Ilude a princípio, perlongando o vale do Cariacá, numa cinta de terrenos férteis sombreados de cerradões que prefiguram verdadeiras matas.

Transcorridos alguns quilômetros, porém, acidenta-se; perturba-se em trilhas pedregosas e torna-se menos praticável à medida que se avizinha do sopé da Serra do Acaru. Dali por diante se encurva pare leste transmontando a serrania por três ladeiras sucessivas, até galgar o sítio da Lajem de Dentro, alçado trezentos metros sobre o vale.

Gastaram-se dois dias pare atingir-se este ponto. A artilharia reduzia a marcha. Ascendiam penosamente os Krupps, enquanto os sapadores na frente reparavam a estrada, desentulhando-a e destocando-a, ou abrindo desvios contornantes, evitando fortíssimos declives. E a tropa, que tinha as condições de sucesso na mobilidade, paralisava-se presa no travão daquelas massas metálicas.

Transposta a Lajem de Dentro e a divisória das vertentes do Itapicuru e do Vaza-Barris, a estrada desce. Torna-se, porém, mais séria a travessia, metendo-se no acidentado de contrafortes, de onde fluem os tributários efêmeros do Bendegó. A bacia de captação deste desenha-se, então, ligando as abas de três serras, a do Acaru, a Grande e do Atanásio, que se articulam em desmedida curva. A expedição entrou por aquele vale fundo como uma furna até a um outro sítio, Ipueiras, onde acampou. Foi uma temeridade. O acampamento, envolto de fraguedos, centralizaria os fogos do inimigo, se este aparecesse pelo topo dos morros. Felizmente não chegavam até lá os jagunços. De sorte que na antemanhã seguinte, rumo firme ao norte, a tropa prosseguiu para Penedo, salve de uma posição dificílima.

Tinha meio caminho andado. As estradas pioravam crivadas de veredas, serpeando em morros, alçando-se em rampas, caindo em grotões, desabrigadas, sem sombras...

Até Mulungu, duas léguas além de Penedo, os sapadores estradaram o solo para os canhões, e a jornada remorava-se no passo tardo da divisão que os guarnecia.

Entretanto era imprescindível a máxima celeridade. Tornava-se suspeita a paragem: restos de fogueiras a margem do caminho e vivendas incendiadas davam sinais do inimigo. Em Mulungu, à noite, eles se tornaram evidentes. Alarmou-se o acampamento. Tinham-se distinguido, próximos, encobertos na sombra, rondando em torno, vultos fugazes, de espias. Os soldados dormiram em armas. E no amanhecer de 17 a expedição que se encravara nas montanhas, muito aquém ainda de um objetivo que podia ser atingido em três dias de marcha, começou de ser terrivelmente torturada.

Acabaram-se as munições de boca. Foram abatidos os dois últimos bois para quinhentos e tantos combatentes. Isto valia por um combate perdido. A feição da luta agravava-se em plena marcha, antes de se dar um tiro. Prosseguir para Canudos, poucas léguas distante, era quase a salvação. Era lutar pela vida.

Completando o transe, desapareceram à noite, em grande parte, os cargueiros contratados em Monte Santo. E, sob o pretexto de providenciar para urgente remessa de munições, o comissário daquela vila largou para ignoradas paragens - e não voltou.

Alguém, entretanto, salvou a lealdade sertaneja, o guia Domingos Jesuíno. Conduziu as tropas para a frente até ao rancho das Pedras, onde acamparam.

Estavam cerca de duas léguas de Canudos. 
E à noite um observador que do acampamento atentasse para o norte, distinguiria talvez, escassas, em bruxuleios longínquos, fulgindo e extinguindo-se, intermitentes, muito altas, como estrelas rubras entre nevoeiros, algumas luzes vacilantes. Demarcavam as posições inimigas.

Ao alvorecer, desdobraram-se imponentes.

\section{Capítulo III}

\section{O Cambaio}

As massas do Cambaio amontoavam-se na frente, dispostas de modo caprichoso, fundamente recortadas de gargantas longas e circulantes como fossos, ou alteando-se em patamares sucessivos, lembrando desmedidas bermas de algum baluarte derruído, de titãs.

A imagem é perfeita. São vulgares naquele trato dos sertões esses aspectos originais da terra. As lendas das "cidades encantadas", na Bahia, que têm conseguido dar à fantasia dos matutos o complemento de sérias indagações de homens estudiosos, originando pesquisas que fora descabido relembrar, não tem outra origem ${ }^{1}$.

E não se acredite que as exagere a imaginação daquelas gentes simples, iludindo tanto a expectativa dos graves respigadores que por ali têm perlustrado, levando ansioso anelo de sabias sociedades ou institutos, onde se debateu o caso interessante. Frios observadores atravessando escoteiros aquele estranho vale do Vaza-Barris têm estacado, pasmos, ao defrontar:

serras de pedra naturalmente sobrepostas formando fortalezas e redutos inexpugnáveis com tal perfeição que parecem obras de arte ${ }^{2}$.

Às vezes esta ilusão se amplia.

Surgem necrópoles vastas. Os morros, cuja estrutura se desvenda em pontiagudas apófises, em rimas de blocos, em alinhamentos de penedias, caprichosamente repartidos, semelham, de fato, grandes cidades mortas ante as quais o matuto passa, medroso, sem desfitar a espora dos ilhais do cavalo em disparada, imaginando lá dentro uma população silenciosa e trágica de almas do outro mundo...

São deste tipo as "casinhas" que se veem para lá do Aracati, perto da estrada de Jeremoabo a Bom Conselho; e outras, despontando por todos

\footnotetext{
${ }^{1}$ Vide tomo 10, e outros, da Revista do Instituto Histórico e Geográfico Brasileiro.

${ }^{2}$ Tenente-coronel Durval de Aguiar, Descrições práticas etc.
} 
aqueles lugares e imprimindo um traço singularmente misterioso naquelas paisagens melancólicas.

\section{Baluartes sine calcii linimenti}

\section{A Serra do Cambaio é um desses monumentos rudes.}

Certo ninguém lhe pode enxergar geométricas linhas de cortinas ou parapeitos bojando em redentes circuitados de fossos. Eram piores aqueles redutos bárbaros. Erigiam-se à têmpera dos que os guarneciam. E à distância, indistintos os ressaltos das pedras e desfeitos os vincos das quebradas, o conjunto da serra incute, de fato, no observador, a impressão de topar, de súbito, fraldejando-a, subindo por ela em patamares sucessivos e estendidas pelas vertentes, as barbacãs de velhíssimos castelos, onde houvessem embatido, outrora, assaltos sobre assaltos que os desmantelaram e aluíram, reduzindo-os a montões de silhares em desordem, mal aglomerados em enormes hemiciclos, sucedendo-se em renques de plintos, e torres, e pilastras truncadas, avultando mais ao longe no aspecto pinturesco de grandes colunatas derruídas...

Porque o Cambaio é uma montanha em ruínas. Surge, disforme, rachando sob o periódico embate de tormentas súbitas e insolações intensas, disjungida e estalada — num desmoronamento secular e lento.

A estrada para Canudos não a torneja. Ajusta-se-lhe, retilínea, às ilhargas, subindo em declive, constrangida entre escarpas, mergulhando por fim, feito um túnel, na angustura de um desfiladeiro. A tropa por ali enfiou...

Naquela hora matinal a montanha deslumbrava. Batendo nas arestas das lajens em pedaços, os raios do sol refrangiam em vibrações intensas alastrando-se pelas assomadas, e dando a ilusão de movimentos febris, fulgores vivos de armas cintilantes, como se em rápidas manobras forças numerosas ao longe se apercebessem para o combate. Os binóculos, entretanto, percorriam inutilmente as encostas desertas. O inimigo traía-se apenas na feição ameaçadora da terra. Encantoara-se. Rentes com o chão, rebatidos nas dobras do terreno, entaliscados nas crastas - esparsos, imóveis, expectantes —, dedos presos aos gatilhos dos clavinotes, os sertanejos quedavam em silêncio, tenteando as pontarias, olhos fitos nas colinas ainda distantes, embaixo, marchando após os exploradores que esquadrinhavam cautelosamente as cercanias.

Caminhavam vagarosamente. Atulhavam as primeiras ladeiras cortadas à meia encosta. Seguiam devagar, sem aprumo, empurradas pelos canhões onde se revezavam soldados ofegantes em auxílio aos muares impotentes à tração vingando aqueles declives.

E foi nesta situação que as surpresou o inimigo.

Dentre as frinchas, dentre os esconderijos, dentre as moitas esparsas, aprumados no alto dos muramentos rudes, ou em despenhos ao viés das vertentes - apareceram os jagunços, num repentino deflagar de tiros. Cambaio.

Toda a expedição caiu, de ponta a ponta, debaixo das trincheiras do

\section{Primeiro recontro}

O recontro fez-se em vozeria em que, através dos costumeiros vivas ao "Bom Jesus" e ao "nosso Conselheiro", rompiam brados escandalosos de linguagem solta, apóstrofes insolentes, e entre outras uma frase desafiadora que no decorrer da campanha soaria invariável como um estribilho irônico:

\section{Avança! fraqueza do governo!}

Houve uma vacilação em toda a linha. A vanguarda estacou e pareceu recuar. Conteve-a, porém, uma voz imperiosa. O major Febrônio rompeu pelas fileiras alarmadas e centralizou a resistência — em réplica fulminante e admirável, atentas as desvantajosas condições em que se realizou. Conteirados rapidamente os canhões, bombardearam os matutos a queima-roupa, e estes, vendo pela primeira vez aquelas armas poderosas, que decuplavam o efeito despedaçando pedras, debandaram, tontos, numa dispersão instantânea.

Aproveitando este refluxo foi feita a investida, iniciada, de pronto, pelas cento e tantas praças do $33^{\circ}$ de Infantaria. Tropeçando, escorregando nas lajens, contornando-as, ou transpondo-as aos saltos, insinuando-se pelos talhados, atirando a esmo para a frente, as praças arremeteram com as rampas; e logo depois a linha do assalto se estirou, tortuosa e ondulante, extremada a direita pelo $9^{\circ}$ e à esquerda pelo $16^{\circ}$ e a polícia baiana. 
O combate generalizou-se em minutos, e, como era de prever, as linhas romperam-se de encontro aos obstáculos do terreno. Foi um avançar em desordem. Fracionados, galgando penhascos a pulso, carabinas presas aos dentes pelas bandoleiras, ou abordoando-se às armas, os combatentes arremeteram em tumulto — sem o mínimo simulacro de formatura, confundidos batalhões e companhias-, vagas humanas raivando contra os morros, num marulho de corpos, arrebentando em descargas, espadanando brilhos de aço, e estrugindo em estampidos sobre que passavam, estrídulas, as notas dos clarins soando a carga.

Embaixo, na ladeira em que ficara a artilharia, os animais de tração e os cargueiros, espavoridos pelas balas, partindo os tirantes, sacudindo fora canastras e bruacas, desapareciam a galope ou tombavam pelas taludes íngremes. Acompanhou-os o resto dos tropeiros, fugindo, surdos às intimativas feitas com revólveres engatilhados, e agravando o tumulto.

No alto, mais longe, pelo teso da serra, reapareciam os sertanejos. Pareciam dispostos em duas sortes de lutadores: os que se agitavam, velozes, surgindo e desaparecendo, às carreiras, e os que permaneciam firmes nas posições alterosas. A cavaleiro do assalto, estes iludiam de modo engenhoso a carência de espingardas e o lento processo de carregamento das que possuíam. Para isto se dispunham em grupos de três ou quatro rodeando a um atirador único, pelas mãos do qual passavam, sucessivamente, as armas carregadas pelos companheiros invisíveis, sentados no fundo da trincheira. De sorte que se alguma bala fazia baquear o clavinoteiro, substituía-o logo qualquer dos outros. Os soldados viam tombar, mas ressurgir imediatamente, indistinto pelo fumo, o mesmo busto, apontando-lhes a espingarda. Alvejavam-no de novo. Viam-no outra vez cair, de bruços, baleado Mas viam outra vez erguer-se, invulnerável, assombroso terrível, abatendo e aprumando-se, o atirador fantástico.

\section{João Grande}

Este ardil foi logo descoberto pelas diminutas frações atacantes que se avantajaram até às canhoneiras mais altas. Chegaram ali esparsas. A fugacidade do inimigo e o terreno davam por si mesmos à tropa distribuição tática mais própria, circunstância que, aliada ao pequeno alcance das armas daquele, tornara a expedição quase indene. Os únicos tropeços à escalada eram as asperezas do solo. As cargas amorteciam-se nas escarpas. Não as esperavam os jagunços. Certos da inferioridade de seu armamento bruto, pareciam desejar apenas que ali ficassem, como ficaram, a maior parte das balas destinadas a Canudos. E falseavam a peleja franca. Via-se entre eles, sopesando o clavinote curto, um negro corpulento e ágil. Era o chefe, João Grande. Desencadeava as manobras, estadeando ardilezas de facínora provecto nas correrias do sertão.... Imitavam-lhe os movimentos, as carreiras, os saltos, as figurações selvagens, os sertanejos amotinados num vaivém de avançadas e recuos, ora dispersos, ora agrupados, ou desfilando em fileiras sucessivas, ou repartindo-se extremamente rarefeitos; e a rojões, rolantes pelos pendores, subindo, descendo, atacando, fugindo, baqueando trespassados de balas, muitos; mal feridos, outros, em plena descida, e rolando até ao meio das praças, que os acabavam a coice de armas.

\section{Desapareciam inteiramente, às vezes.}

Os projetis das Mannlichers estralavam à toa na ossamenta rígida da serra. As seções avançadas ascendiam, porém, mais rápidas, pelas barrancas; conquistando o terreno, até que outra irrupção repentina do adversário lhes tomasse a frente, ou as aferrasse de soslaio. Algumas, então, paravam. Algumas recuavam mesmo, tolhidas de espanto, sem que as animassem oficiais acovardados, cujos nomes pouparam as partes oficiais, mas não os comentários acerbos dos companheiros. A maior parte reagia. Rompia o espingardeamento à queima-roupa sobre os fanáticos dizimandoos, espalhando-os, em grandes correrias pelos cerros.

Por fim o rude cabecilha predispô-los, ao que se figura, a recontro decisivo, braço a braço. O seu perfil de gorila destacou-se temerariamente à frente de um bando de súbito congregado. Num belo movimento heroico avançou sobre a artilharia. Cortou-lhe, porém, o passo a explosão de uma lanterneta estraçoando-o e aos caudatários mais próximos, enquanto os demais fugiam para as posições primitivas de envolta, agora, com as avançadas da tropa. Contingentes misturados de todos os corpos saltavam afinal dentro das ultimas trincheiras à direita, perdendo o oficial que até lá os levara, Venceslau Leal.

Estava conquistada a montanha após três horas de conflito. A vitória, porém, resultava da coragem cega junta à mais completa indisciplina de 
fogo - e compreende-se que mais tarde a ordem do dia relativa ao feito desse preeminente lugar às praças graduadas. Os seus cabos de guerras foram os cabos de esquadra. Sobre os jagunços em fuga confluíram cargas em desordem: soldados em grupos, turbas sem comando, disparando à toa as carabinas, num fanfarrear irritante e numa alacridade feroz de monteiros no último lance de uma batida a javardos.

Os jagunços escapavam-se-lhes adiante. Perseguiram-nos.

A artilharia, embaixo, começou a rodar, puxada a pulso, pelas ladeiras acima.

Realizara-se a travessia; e, tirante o dispêndio de munições, eram poucas as perdas-quatro mortos e vinte e tantos feridos. Em troca os sertanejos deixaram 115 cadáveres, contados rigorosamente.

\section{Episódio trágico}

Fora uma hecatombe Cumulou-a um episódio trágico.

A algara tumultuária teve um desfecho teatral.

Foi no volver das últimas bicadas da serra...

Ali sobre barranca agreste, avergoada de algares, se alteava, oblíqua e mal tocando por um dos extremos o solo, imensa lajem presa entre duas outras que a sustinham pelo atrito, semelhando um dólmem abatido. Este abrigo coberto tinha, na frente, a barbacã de um muro de rocha viva. Nele se acoitaram muitos sertanejos - cerca de quarenta, segundo um espectador do quadro ${ }^{3}$ — provavelmente os que possuíam as derradeiras cargas dos trabucos.

A terra protetora dava aos vencidos o último reduto.

Aproveitaram-no. Abriam sobre os perseguidores um tiroteio escasso, e fizeram-nos estacar um momento, fazendo parar, mais longe, a artilharia que se aprestou a bombardear o pequeno grupo de temerários.
O bombardeio reduziu-se a um tiro. A granada partiu levemente desviada do alvo, e foi arrebentar numa das junturas em que se engastava a pedra. Dilatou-a. Abriu-a, de alto a baixo.

E o bloco despregado desceu pesadamente, em baque surdo, sobre os infelizes, sepultando-os...

Reatou-se a marcha. Adiante, numa exaustão crescente, percebida no rarear dos tiros, os últimos defensores do Cambaio tocavam para Canudos. Desapareceram, por fim. 


\section{Capítulo IV}

\section{Nos Tabuleirinhos}

As colunas chegaram à tarde em Tabuleirinhos, quase à orla do arraial, e não prosseguiram aproveitando o ímpeto da marcha perseguidora. Combalidos da refrega e famintos desde a véspera, tiveram apenas abrandada a sede na água impura da lagoa minúscula do Cipó, e acamparam. Fizeram-no, porém, com o desleixo das fadigas acumuladas e, talvez, também com a ilusão enganadora do triunfo recente. De sorte que não pressentiram, em torno, a sobre-rolda dos jagunços. Porque a nova da investida chegara ao arraial com os foragidos; e para quebrar o ímpeto do invasor sobrestante, grande número de lutadores de lá partiram. Meteramse, imperceptíveis, pelas caatingas; e aproximaram-se do acampamento.

À noite circularam-no. A tropa adormeceu sob a guarda terrível do inimigo..

\section{Segundo combate}

Ao amanhecer, porém, nada lho revelou; e, formadas cedo, as colunas dispuseram-se ao último arranco sobre o arraial, depois de um quarto de hora a marche-marche sobre o terreno, que ali é desafogado e chão.

Mas antes de abalarem sobreveio ligeiro contratempo. Um shrapnel emperrara na alma de um dos canhões resistindo a todos os esforços para a extração. Adotou-se, então, o melhor dos alvitres: disparar o Krupp na direção provável de Canudos.

Seria uma aldravada batendo às portas do arraial, anunciando estrepitosamente o visitante importuno e perigoso.

De fato, o tiro partiu... E a tropa foi salteada por toda a banda! Reeditou-se o episódio de Uauá. Abandonando as espingardas imperfeitas pelos varapaus, pelos fueiros dos carros, pelas foices, pelas forquilhas, pelas aguilhadas longas e pelos facões de folha larga, os sertanejos enterreiraram- na, surgindo em grita, todos a um tempo, como se aquele disparo lhes fosse um sinal prefixo para o assalto.

Felizmente os expedicionários, em ordem de marcha, tinham prontas as armas para a réplica, que se realizou logo em descargas rolantes e nutridas.

Mas os jagunços não recuaram. $\mathrm{O}$ arremesso da investida jogara-os dentro dos intervalos dos pelotões. E pela primeira vez os soldados viam, de perto, as faces trigueiras daqueles antagonistas, até então esquivos, afeitos às correrias velozes nas montanhas...

A primeira vítima foi um cabo do $9^{\circ}$. Morreu matando.

Ficou trespassado na sua baioneta o jagunço que o abatera atravessando-o com o ferrão de vaqueiro.

A onda assaltante passou sobre os dois cadáveres.

Tomara-lhe a frente um mamaluco possante - rosto de bronze afeiado pela pátina das sardas - , de envergadura de gladiador sobressaindo no tumulto. Este campeador terrível ficou desconhecido à história. Perdeuse-lhe o nome. Mas não a imprecação altiva que arrojou sobre a vozeria e sobre os estampidos, ao saltar sobre o canhão da direita, que abarcou nos braços musculosos, como se estrangulasse um monstro:

Viram, canalhas, o que é ter coragem?!

A guarnição da peça recuara espavorida, enquanto ela rodava, arrastada a braço, apresada.

Era o desastre iminente.

Avaliou-o o comandante expedicionário, que tudo indica ter sido o melhor soldado da própria expedição que dirigia. Animou valentemente os companheiros atônitos e, dando-lhes o exemplo, precipitou-se contra o grupo. E a luta travou-se braço a braço, brutalmente, sem armas, a punhadas, quase surda: um torvelinho de corpos enleados, de onde se difundiam estertores de estrangulados, ronquidos de peitos ofegantes, baques de quedas violentas...

O canhão retomado volveu à posição primitiva. As coisas, porém, não melhoraram. Apenas repelidos os jagunços, num retroceder repentino 
que não era uma fuga, mas uma negaça perigosa, fervilhavam no matagal rarefeito, em roda: vultos céleres, fugazes, indistintos, aparecendo e desaparecendo nos claros das galhadas. Novamente esparsos e intangíveis, punham, ressoantes, sobre os contrários, os projetis grosseiros - pontas de chifre, seixos rolados, e pontas de pregos - de sua velha ferramenta da morte, desde muito desusada ${ }^{1}$. Renovavam o duelo à distância, antepondo as espingardas de pederneira e os trabucos de cano largo às Mannlichers fulminantes. Volviam ao sistema habitual de guerra, o que era delongar indefinidamente a ação, dando-lhe um caráter mais sério que o do ataque violento anterior, fazendo-a derivar cruelmente monótona, sem peripécias, na iteração fatigante dos mesmos incidentes, até ao esgotamento completo do adversário que, relativamente incólume, cairia afinal exausto de os bater, vencido pelo cansaço de minúsculas vitórias, num asfaltamento trágico de algozes enfastiados de matar; punhos amolecidos e frouxos pelo multiplicado dos golpes; forças perdidas em arremessos doidos contra o vácuo.

\section{A situação desenhou-se insanável.}

Restava aos invasores um recurso em desespero de causa: - o avançar aforradamente, deslocando o campo do combate, e cair sobre o arraial, assaltantes e assaltados, tendo às ilhargas os guerrilheiros atrevidos, e talvez na frente, antes da entrada daquele, outros reforços tolhendo-lhes o passo. Mas, nesse pelejar em marcha de três quilômetros, as munições, prodigamente gastas na façanha prejudicial do Cambaio, talvez se extinguissem em caminho e não podia alvitrar-se o meio extremo de se ultimar a empresa a choques de armas brancas, ante a sobrecarga muscular dos soldados famintos e combalidos a que se aditavam cerca de setenta feridos, agitando-se, inúteis, na desordem.

Estava, além disto, excluída a hipótese eficaz de um bombardeio preliminar: restavam apenas vinte litros de artilharia.

A retirada impôs-se urgente e inevitável. Reunida em plena refrega a oficialidade, o comandante definiu-lhe a situação e determinou que optasse por uma das pontas do dilema: o prosseguimento da luta até ao sacrifício completo ou o seu abandono imediato. Foi aceita a última sob a condição

\footnotetext{
${ }^{1}$ Os incidentes desta jornada, devo-os ao depoimento fidedigno do Dr. Albertazzi.
}

expressa de não se deixar uma única arma, um único ferido e não ficar um único cadáver insepulto.

Este recuo, entretanto, era de todo contraposto aos resultados diretos do combate. Como na véspera, as perdas sofridas de um e outro lado estavam fora de qualquer paralelo. A tropa perdera apenas quatro homens, excluídos trinta e tantos feridos, ao passo que os contrários, desconhecidos o número dos últimos, foram dizimados.

Um dos médicos ${ }^{2}$ contou rapidamente mais de trezentos cadáveres. Tingira-se a água impura da lagoa do Cipó e o Sol, batendo de chapa na sua superfície, destacava-a sinistramente no pardo escuro da terra requeimada, como uma nódoa amplíssima, de sangue...

\section{A Legio Fulminata de João Abade}

A retirada foi a salvação. Mas o investir de arranco com o arraial, arrostando tudo, talvez fosse a vitória.

Desvendemos - arquivando depoimentos de testemunhas contestes - um dos casos originais dessa campanha. Algum tempo depois de travado o conflito em Tabuleirinhos, os habitantes de Canudos, impressionados com a intensidade dos tiroteios, alarmaram-se; e prevendo as consequências que adviriam se os soldados ali chegassem, de chofre, caindo sobre a beataria medrosa, João Abade reuniu o resto dos homens válidos, cerca de seiscentos, seguindo em reforço aos companheiros. A meio caminho, porém, a sua coluna foi inopinadamente colhida pelas balas. Atirando contra os primeiros agressores no lugar do encontro, os soldados mal apontavam; de sorte que, na maior parte, os tiros, partindo em trajetórias altas, se lançavam segundo o alcance máximo das armas. Ora, todos estes projetis perdidos, passando sobre os combatentes, iam cair, adiante, no meio da gente de João Abade. Os jagunços, perplexos, viam os companheiros baqueando, como fulminados; percebiam o assovio tenuíssimo das balas e não lobrigavam o inimigo. Em torno dos arbúsculos estonados e raros não permitiam tocaias; os cerros mais próximos viam-se desnudos, desertos. E as balas desciam incessantes, aqui, ali, de soslaio, de frente, pelo centro da legião surpreendida, pontilhando-a de mortos -

\footnotetext{
${ }^{2}$ Dr. Everard Albertazzi.
} 
como uma chuva silenciosa de raios... Um assombro supersticioso sombreou logo nos rostos mais enérgicos. Volveram, atônitos, as vistas para o firmamento ofuscante, varado pelos ramos descendentes das parábolas invisíveis; e não houve, depois, contê-los. Precipitaram-se, desapoderadamente, para Canudos, onde chegaram originando alarma espantoso.

Não havia ilusão possível: o inimigo, dispondo de engenhos de tal ordem, ali estaria em breve, sobrestante, no rastro dos derradeiros defensores do arraial. Quebrou-se o encanto do Conselheiro. Tonto de pavor, o povo ingênuo perdeu, em momentos, as crenças que o haviam empolgado. Bandos de fugitivos, sobraçando trouxas estavanadamente feitas, porfiavam na fuga, atravessando rápidos, a praça e os becos, demandando as caatingas, sem que as contivessem os cabecilhas mais prestigiosos; enquanto as mulheres, em desalinho, em gritos, soluçando, clamando, numa algazarra indefinível, mas ainda fascinadas, agitando os relicários, rezando, se agrupavam à porta do Santuário implorando a presença do evangelizador.

\section{Novo milagre do Conselheiro}

Mas Antônio Conselheiro, que nos dias normais mesmo evitava encará-las, naquelas aperturas estabeleceu separação completa. Subiu com meia dúzia de fiéis para os andaimes altos da igreja nova, e fez retirar, depois, a escada.

O agrupamento agitado ficou embaixo, imprecando, chorando, rezando. Não o olhou sequer o apóstolo esquivo, atravessando impassível sobre as tábuas que infletiam, rangendo. Atentou para o povoado revolto, em que se atropelavam, prófugos, os desertores da fé, e preparou-se para o martírio inevitável...

Neste comenos sobreveio a nova de que a força recuava.

Foi um milagre. A desordem desfechava em prodígio.

\section{Capítulo V}

\section{Retirada}

Começara, de fato, a retirada.

Extintas as esperanças de sucesso, resta aos exércitos infelizes o recurso desse oscilar entre a derrota e o triunfo, numa luta sem vitórias em que, entretanto, o vencido vence em cada passo que consegue dar para a frente, pisando, indomável, o território do inimigo - e conquistando a golpes de armas todas as voltas dos caminhos.

Ora, a retirada do major Febrônio se, pelo restrito do campo em que se operou, não se equipara a outros feitos memoráveis, pelas circunstâncias que a enquadraram é um dos episódios mais emocionantes de nossa história militar. Os soldados batiam-se ia para dois dias, sem alimento algum, entre os quais mediava o armistício enganador de uma noite de alarmas; cerca de setenta feridos enfraqueciam as fileiras; grande número de estropiados mal carregavam as armas; os mais robustos deixavam a linha de fogo para arrastarem os canhões ou arcavam sob feixes de espingardas, ou, ainda, em padiolas, transportavam malferidos e agonizantes; - e, na frente desta multidão revolta, se estendia uma estrada de cem quilômetros, em sertão maninho, inçado de tocaias...

Ao perceberem o movimento, os jagunços encalçaram-na.

Capitaneava-os, agora, um mestiço de bravura inexcedível e ferocidade rara, Pajeú. Legítimo cafuz, no seu temperamento impulsivo acolchetavam-se todas as tendências das raças inferiores que o formavam. Era o tipo completo do lutador primitivo - ingênuo, feroz e destemeroso - simples e mau, brutal e infantil, valente por instinto, herói sem o saber — um belo caso de retroatividade atávica, forma retardatária de troglodita sanhudo aprumando-se ali com o mesmo arrojo com que, nas velhas idades, vibrava o machado de sílex à porta das cavernas...

Este bárbaro ardiloso distribuiu os companheiros pelas caatingas, ladeando as colunas. 
Estas marchavam lutando. Dando um último choque partindo o círculo assaltante, começou a desfilar pelas veredas ladeirentas, sem que se lobrigasse, neste movimento gravíssimo, o mais sério das guerras, o mais breve resquício de preceitos táticos, onde avulta a clássica formatura em escalões, permitindo às unidades combatentes alternarem-se na repulsa.

É que a expedição perdera de todo em todo a estrutura militar, nivelados oficiais e praças de pré pelo mesmo sacrifício. Enquanto o comandante, cujo ânimo não afrouxara, procurava os pontos mais arriscados; enquanto capitães e subalternos sobraçando carabinas, se precipitavam, de mistura com as praças de pré, em cargas feitas sem vozes de comando, um sargento, contra todas as praxes, dirigia a vanguarda.

Desta maneira penetravam de novo nas gargantas do Cambaio. Ali estava a mesma passagem temerosa, estreitando-se em gargantas, ou içada à meia encosta, num releixo sobre os abismos; entalando-se entre escarpas; aberta a esmo ao viés das vertentes; sobranceada em todo o percurso pelas trincheiras alterosas. Uma variante apenas: de bruços ou de supino sobre as pedras, desenlapando-se à boca das furnas, esparsos pelas encostas, viam-se os jagunços vitimados na véspera.

Os companheiros sobreviventes passavam-lhes, agora, de permeio, parecendo uma turba vingadora de demônios entre caída multidão de espectros...

Não arremetiam mais em chusma sobre a linha, desafiando as últimas granadas; flanqueavam-na, em correrias pelos altos, deixando que agisse quase exclusiva, a sua arma formidável - a terra. Esta bastava-lhes. O curiboca que partira a lazarina ou perdera o ferrão no torvelinho volvia o olhar em torno - e a montanha era um arsenal. Ali estavam blocos esparsos ou arrumados em pilhas vacilantes prestes a desencadear o potencial de quedas violentas, pelos declives. Abarcava-os; transmudava a espingarda imprestável em alavanca; e os monólitos abalados oscilavam, e caíam, e rolavam, a princípio em rumo incerto entre as dobras do terreno, depois, mais rápidos, pelas normais de máximo declive, despenhando-se, por fim, vertiginosamente, em saltos espantosos; e batendo contra as outras pedras, e esfarelando-as em estilhas, passavam como balas rasas monstruosas sobre as tropas apavoradas.
Estas, embaixo, salvavam-se cobertas pelo ângulo morto do próprio caminho à meia encosta, sob uma avalanche de blocos e graeiros. As fadigas da marcha abatiam-nas mais que o inimigo. O Sol culminara ardente e a luz crua do dia tropical, caindo na região pedregosa e despida, refluía aos espaços num flamejar de queimadas grandes alastrando-se pelas serras.

A natureza toda quedava-se imóvel naquele deslumbramento, sob o espasmo da canícula. Os próprios tiros mal quebravam o silêncio: não havia ecos nos ares rarefeitos, irrespiráveis. Os estampidos estalavam, secos, sem ressoarem; e a brutalidade humana rolava surdamente dentro da quietude universal das coisas...

A travessia das trincheiras foi lenta.

Entretanto, os sertanejos por bem dizer não agrediam.

Num tripúdio de símios amotinados pareciam haver transmudado tudo aquilo num passatempo doloroso e num apedrejamento. Desfilavam pelos altos em corrimaças turbulentas e ruidosas. Os lutadores embaixo seguiam como atores infelizes, no epílogo de um drama mal representado. Toda a agitação de dois dias sucessivos de combates e provações tinha o repentino desfecho de uma arruaça sinistra. Piores que as descargas, ouviam brados irônicos e irritantes, cindidos de longos assovios e cachinadas estrídulas, como se os encalçasse uma matula barulhenta de garotos incorrigíveis.

Assim chegaram, ao fim de três horas de marcha, a Bandegó de Baixo. Salvou-os a admirável posição desse lugar, breve planalto em que se complana a estrada, permitindo mais eficazes recursos de defesa.

O último recontro aí se fez, ao cair da noite, à meia luz dos rápidos crepúsculos do sertão.

Foi breve, mas temeroso. Os jagunços deram a última investida com a artilharia, que timbravam em arrebatar à tropa. As metralhadoras, porém, disparadas a cavaleiro, rechaçaram-nos; e, varridos à metralha, deixando vinte mortos, rolaram para as baixadas perdendo-se na noite...

Estavam findas as horas de provações. 
Um incidente providencial completou o sucesso. Fustigado talvez pelas balas, um rebanho de cabras ariscas invadiu o acampamento, quase ao tempo em que refluíam os sertanejos repelidos. Foi uma diversão feliz. Homens absolutamente exaustos apostaram carreiras doidas com os velozes animais em torno dos quais a força circulou delirante de alegria, prefigurando os regalos de um banquete, após dois dias de jejum forçado; e, uma hora depois, acocorados em torno das fogueiras, dilacerando carnes apenas sapecadas — andrajosos, imundos, repugnantes —, agrupavam-se, tintos pelos clarões dos braseiros, os heróis infelizes, como um bando de canibais famulentos em repasto bárbaro...

\section{A expedição no outro dia, cedo, prosseguiu para Monte Santo.}

Não havia um homem válido. Aqueles mesmos que carregavam os companheiros sucumbidos claudicavam, a cada passo, com os pés sangrando, varados de espinhos e cortados pelas pedras. Cobertos de chapéus de palha grosseiros, fardas em trapos, alguns tragicamente ridículos mal velando a nudez com os capotes em pedaços, mal alinhando-se em simulacro de formatura, entraram pelo arraial lembrando uma turma de retirantes, batidos dos sóis bravios, fugindo à desolação e à miséria.

A população recebeu-os em silêncio.

\section{Capitulo VI}

\section{Procissão dos jiraus}

Naquele mesmo dia, à tarde, animaram-se de novo as encostas do Cambaio. O fragor dos combates, porém, trocara-se pela assonância das litanias melancólicas. Lentamente, caminhando para Canudos, extensa procissão derivava pelas serras. Os crentes substituíam os trabalhadores e volviam para o arraial, carregando aos ombros, em toscos pálios de jiraus de paus roliços amarrados com cipós, os cadáveres dos mártires da fé.

O dia fora despendido na lúgubre pesquisa, a que se dedicara a população inteira. Haviam-se esquadrinhado todas as anfractuosidades, e todos os dédalos rasgados entre pedras, e todos os algares fundos, e todas as taliscas apertadas...

Muitos lutadores ao baquearem pelas ladeiras, em resvalos, tinham caído em barrocais e grotas; outros, mal seguros pelas arestas pontiagudas das rochas atravessando-lhes as vestes, balouçavam-se sobre abismos; e, descendo às grotas profundas, e alando-se aos vértices dos fraguedos abruptos, colhiamnos os companheiros compassivos.

À tarde ultimava-se a missão piedosa.

Faltavam poucos, os que a tropa queimara.

O fúnebre cortejo seguia agora para Canudos...

Muito baixo no horizonte, o Sol descia vagarosamente, tangenciando com o limbo rutilante o extremo das chapadas remotas, e o seu último clarão, a cavaleiro das sombras, que já se adunavam nas baixadas, caía sobre o dorso da montanha... Aclarou-o por momentos. Iluminou, fugaz, o préstito, que seguia à cadência das rezas. Deslizou, insensivelmente, subindo, à medida que lentamente ascendiam as sombras, até ao alto, onde os seus últimos raios cintilaram nos píncaros altaneiros. Estes fulguravam por instantes, como enormes círios, prestes acesos, prestes apagados, bruxuleando na meia luz do crepúsculo.

Brilharam as primeiras estrelas. Rutilando na altura, a cruz resplandescente de Órion alevantava-se sobre os sertões... 